\title{
気候変動に伴う可能最大高潮の不確実性の評価に関する研究 \\ Uncertainty of Possible Maximum Storm Surge Projection Associated with Climate Change
}

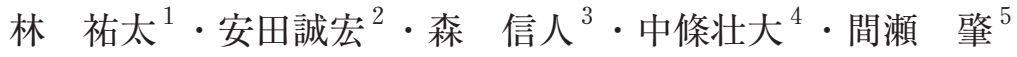

Yuta HAYASHI, Tomohiro YASUDA, Nobuhito MORI, Sota NAKAJO and Hajime MASE

Although evaluation of possible maximum storm surge risk is important in a long-term design of coastal defence structures, the storm surge risk depends not only on typhoon's intensification but also on typhoon's track shift due to climate change. This study investigates uncertainty of possible maximum storm surge projections. Effects of model parameters, such as sea surface drag coefficient, radiation stress, and climate change effects on potential storm surge magnitude in Ise Bay were analysed. Numerical results indicate that an empirical typhoon model with proper parameterization of the bulk flux is reasonable comparing with mesoscale downscaling results, and also demonstrated that not only typhoon track's shift but also typhoon's translation angle against the bay shape is important in projections of possible maximum storm surge.
\end{abstract}

\section{1. 緒 論}

近年，全球気候モデル GCMによる結果を用いて，様々 な気候変動の影響評価研究が進められている。 GCMや RCMなどの高解像度気候モデルによる予測実験では, 気 候変動に伴い, 全球での熱帯低気圧の発生頻度は減少す るが，強度は増大することが示されている（Knutsonら， 2010).ささら，北西太平洋，なかでも日本付近で台風強 度の変化により風速の極值が増大すると予測されている (Mori ら，2010）。日本沿岸においては, 台風強度の増加 により，高潮による災害の甚大化が懸念される。

護岸設計に打ける設計潮位は，既往最高潮位，または 最悪コースを通る伊勢湾台風級の台風を外力として推算 された高潮偏差に朔望平均満潮位を足し合わせたものの いずれか大きい方が用いられる，将来の高潮を予測する 場合, GCMのモデル間の差や解像度, 温室効果ガス排出 シナリオなどの種々の要因によって, 予測結果には不確 実性が含まれる，特に台風のような複雑な構造をもつ気 象擾乱を再現するためには， GCM は最低でも数十 $\mathrm{km}$ 程 度の水平分解能を要する。安田ら（2011）は, 最新の予 測実験結果を直接外力として用いて，日本沿岸の高潮の 将来変化を求めているが, 1 つの $\mathrm{GCM}$ モデルと 1 つの $\mathrm{CO}_{2}$ 排出シナリオに基づいた結果であるため, 湾スケー ルの不確実性の評価をするまでには至っていない，将来 気候下に扔ける高潮の可能最大值を求めること（吉野ら, 2009; 林ら，2011; 村上ら，2011）は，長期的な護岸設計 において重要であるが, 考慮すべき対象が多岐にわたる.

1 正会員 修(工) 五洋建設株式会社

2 正会員博(工) 京都大学助教 防災研究所

3 正会員博(工) 京都大学准教授 防災研究所

4 正会員 博(工) 熊本大学助教 工学部社会環境工学科

5 正会員 工博 京都大学教授 防災研究所
高潮は単に台風強度の将来変化だけでなく, 台風がどの ような経路をとるかにより大きく変化する，さらに，高 潮推算に扔いても，用いる数值計算モデルやモデルパラ メー夕，外力となる気象場などによって推算結果に差が 生じる. 可能最大高潮の推定抒よび将来高潮変化予測を 行うには，これらをすべて踏まえる必要がある.

本研究では, 伊勢湾を対象として, 高潮計算モデルと 台風特性が可能最大高潮予測に係る不確実性について評 価する。

\section{2. 検討手法および条件}

高潮予測の不確実性に影響を及ぼす要因として，1）高 潮計算モデルと2）台風特性が考えられる。高潮モデル による不確実性としては，a）計算格子解像度，b）ラデ イエーションストレス，c）入力気象場，d）海面抵抗係 数が考えられる. 台風特性による不確実性としては，e) 台風経路 (平行移動と回転), f) 台風の移動速度, g) 気 候変動に伴う台風強度の将来変化が考えられる。これら の項目を変えて計算を実施し, 結果の差異を評価する.

計算には, 高潮・波浪結合モデル SuWAT（Kimら， 2008）を用い，伊勢湾台風を対象として，上記の $\mathrm{a} ） \sim \mathrm{g}$ ) の7つの要因について定量的な評価を実施した.

\section{（1）高潮計算モデルの不確実性}

\section{a) 格子解像度}

高潮の発生機構のひとつである吹き寄せ効果は, 水深 に反比例するので，高潮は水深変化に鋭敏に反応する. さらに, 東京湾, 伊勢湾のような内湾は, 複雑な海岸線 かつ海底地形を有しているため, 高潮推算を行う上で, ある程度の解像度で地形を適切に表現することが必要で ある、計算条件としては, 入力気象場に伊勢湾台風の詳 細気象予測值（別所ら，2010), 海面抵抗係数にJanssen 
による波齢に依存した海面抵抗係数, 波浪モデルと結合 してラディエーションストレスを考慮する.

\section{b) ラディエーションストレス}

波浪モデルとの結合によるラディエーションストレス の影響が高潮推算值に影響を及ぼすことは，柴木ら （2001）やKimら（2010）によって高知海岸を対象に示 されているが，ここでは伊勢湾における影響を確認する. 計算条件としては, 詳細気象予測值を入力気象場とし, 海面抵抗係数については, 波浪モデルとの結合の場合は Janssenの海面抵抗係数を, 結合しない場合は本多・光易 式を用いる。

\section{c) 入力気象場}

間瀬ら（2011）は, 別所ら（2010）がJRA-55を気象庁 非静力学モデル（NHM）によりダウンスケールした詳細 気象予測值を用いて, 伊勢湾台風高潮の再現実験を行っ ている。ここでは，間瀬ら（2011）の結果と経験的台風 モデル（Myers式および藤井・光田（1986）のSGW）を 入力気象場とした高潮推算結果を比較する. 波浪モデル を結合して計算を行い，Janssenの海面抵抗係数を用いる.

\section{d) 海面抵抗係数}

モデル内のパラメータの設定によって高潮推算結果に 違いが生じる. 海面抵抗係数 $C_{D}$ の違いによる高潮推算へ の影響をみるために，海面と波浪の相互作用を考慮した $C_{D}$ と本多・光易式（1980）およびGarratt（1977）の経験 式で求められる $C_{D}$ を与えた計算をそれぞれ実施する.

（2）台風特性の不確実性

\section{a）台風経路}

台風経路が高潮に及ぼす不確実性について評価するた め，伊勢湾台風を平行・回転移動させた経路を用いて高 潮推算を行い, 名古屋港に対する危険経路および高潮の 可能最大值を求める. 平行移動については, 元の経路デ

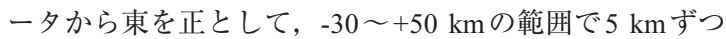
移動させる. 回転移動については, 名古屋港を中心とし て, 反時計回りを正として, $-30^{\circ} \sim+30^{\circ}$ の範囲で $5^{\circ}$ 刻み で回転操作を行う，回転中心を名古屋港としたのは，経 験的台風モデルでは, 台風中心を原点として台風の進行 方向を座標軸としたとき，同じ座標では同じ風速・気圧 が推算され, 風向のみが変わる性質を利用するためであ る. 海面抵抗係数には，3. (4) での検証結果より， $U_{10} \geq$ $30 \mathrm{~m} / \mathrm{s}$ の $C_{D}$ を一定とする条件を, 最適条件として用いる.

\section{b）移動速度}

台風の移動速度の変化に伴い, 風速も変化する。また, 移動速度が湾固有の長波の速度と等しくなる場合，共振 が発生する．伊勢湾台風の移動速度を上陸直前の1959年 9月26日 15 時 (JST) から台風が通過するまで変化させ る. 元の伊勢湾台風の移動速度を $1 / 6,1 / 3,1 / 2,2,3$ 倍 と変化させて高潮計算を行う。

\section{c）台風強度の将来変化}

気候変動による台風強度の将来変化を考慮するため に，4.（1）の検討で得られる危険経路に, 台風強度の将 来変動予測值を加味した高潮計算を行う. 経験的台風モ デルでは中心気圧に応じた風速場が求められるため，台 風強度の変化は中心気圧で表わせるものとして, 中心気 圧のみを変化させる. 中心気圧の将来変化は, 気象研究 所（Kitoh ら, 2009）のCMIP5 全球大気モデルの2モデル と CMIP3の中から6モデルを用い, 緯度依存する中心気 圧の将来変化傾向 $\Delta p[\mathrm{hPa}]$ （Mori, 2012）を上乗せする. 将来気候下の極端な例を想定するために，将来変化傾向 の標準偏差 $\sigma[\mathrm{hPa}]$ を $\Delta p$ に加えた場合も検討し, 中心気 圧の将来変化の不確実性についても考慮する.

\section{3. 計算モデルが高潮予測に及ぼす不確実性}

\section{（1）格子解像度}

格子解像度が高潮推算精度に与える影響を評価する。 名古屋港と四日市, 前芝においては時系列で潮位偏差の 観測值があるので時系列で計算結果と比較し，松坂と鳥 羽における観測值は最大潮位偏差のみであるため, 最大 潮位偏差は 5 地点すべてで比較する。

名古屋における計算結果の潮位偏差の時系列を図-1に

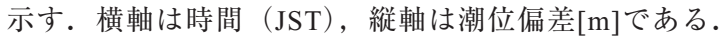
また, 黒は観測值で, 緑, 青, 赤はそれぞれ第 $1,2,3$ 領 域の計算結果を示している. 黒線が途切れているのは, 観測值が久損しているためである. 格子解像度による計 算結果の差異は顕著であり, 解像度 $500 \mathrm{~m}, 1 \mathrm{~km}$ （青, 赤）と $5 \mathrm{~km}$ (緑) を比較すると, ピーク到達時刻に約 1 〜2時間ほどの差がある. 最大潮位偏差にも顕著な差が あり, 解像度 $500 \mathrm{~m}$ と $5 \mathrm{~km}$ では約 $1.0 \mathrm{~m}$ の差がある. ピ 一ク到達前の前駆的な高潮の再現性が良くないが，これ は, 入力気象場である詳細気象予測值が，ピーク到達前 の 12 時間前からしかないことによる, Forerunnerの影響 と考えられる.

次に, 最大潮位偏差の解像度による違いをみる。最大 潮位偏差の観測值と計算值を比較したものを図-2に示 す. 湾口に近い鳥羽や松坂に比べて, 湾奥にある名古屋

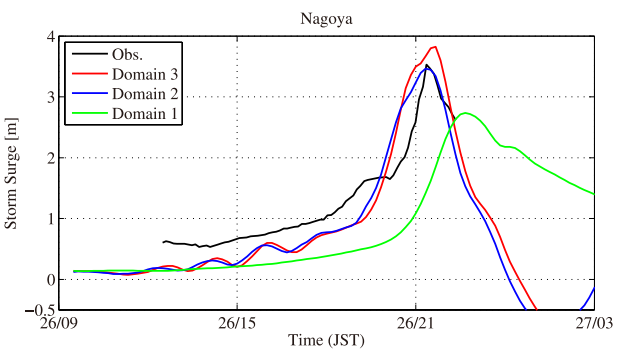

図-1 格子解像度の違いによる高潮偏差の時系列 (黒: 観測值, 緑：解像度 $5 \mathrm{~km}$, 青: 解像度 $1 \mathrm{~km}$, 赤：解像度 $500 \mathrm{~m}$ ) 


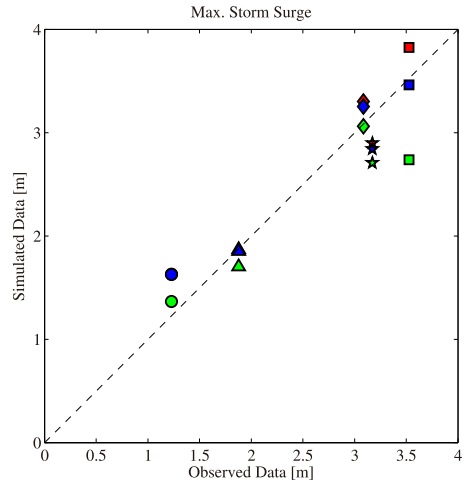

図-2 格子解像度の違いによる最大高潮の観測值と計算值の

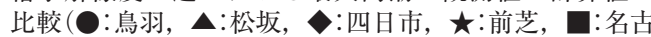
屋. 緑: 解像度 $5 \mathrm{~km}$, 青: 解像度 $1 \mathrm{~km}$, 赤: 解像度 $500 \mathrm{~m}$ )

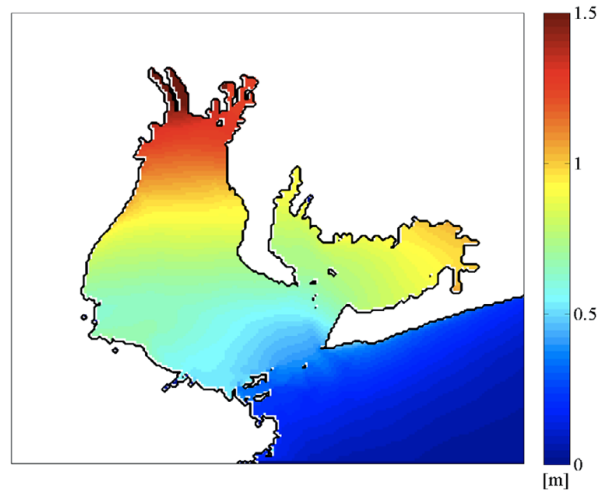

図-3 波浪モデル結合の有無による最大高潮偏差の差（波浪 モデル結合ありー結合なし)

では格子解像度の影響がより大きい. 名古屋では $0.9 \mathrm{~m}$ の差があるが，四日市や前芝，松坂，鳥羽では $0.3 \sim 0.1$ $\mathrm{m}$ 程度であった。

(2) ラディエーションストレス

図-3に波浪モデルの結合の有無による最大潮位偏差の 差の平面分布を示す。波浪モデル結合ありの場合，ラデ イエーションストレスが考慮される．值は波浪モデル結 合ありの結果から結合なしの結果を差し引いた值であ る. その差は, 湾口から湾奥に向かうほど大きくなり, 伊勢湾の湾奥では推算結果に $1.2 \sim 1.75 \mathrm{~m}$ の差が生じる.

\section{(3) 入力気象場}

名古屋での高潮偏差の時系列を図-4に示す。横軸は時 間（JST），縦軸は潮位偏差である。黑は観測值，赤は詳 細気象予測值による間瀬らの計算値，青は経験的台風モ デルによる計算值である。詳細気象予測值による最大高 潮偏差の值は，観測值とほほ一致している。一方，経験 的台風モデルによる計算值は，名古屋で最大值が約 $5.9 \mathrm{~m}$ となっており，推算精度は良くない. ピーク到達前の潮 位偏差についても，経験的台風モデルによる結果は過小 評価している．経験式による $C_{D}$ は伊勢湾台風のような高

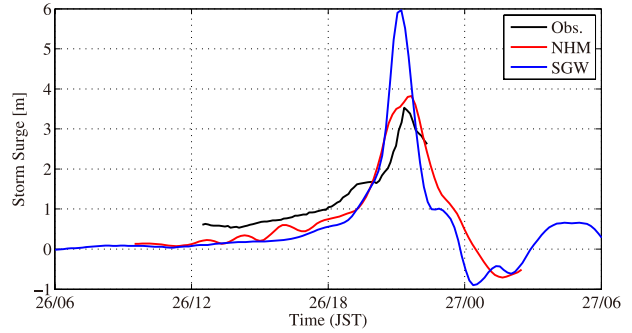

図-4 入力気象場の違いによる名古屋での高潮偏差の時系列 比較 (黒：観測值，赤：詳細気象予測值 (NHM), 青： 経験的台風モデル $(\mathrm{SGW}))$

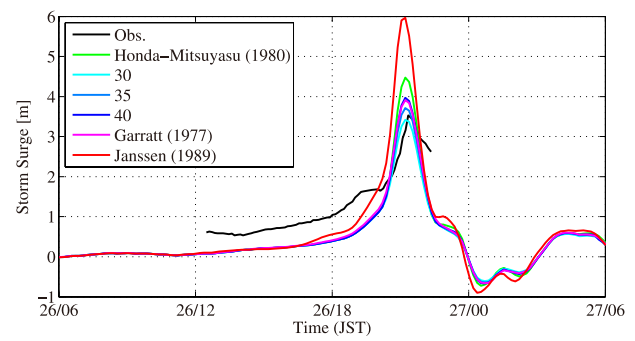

図-5 海面抵抗係数の違いによる名古屋での高潮偏差の時系 列比較（黒：観測值，赤：波浪と海面の相互作用を考 慮した $C_{D}$ (図-4の SGWに相当), 緑：本多・光易式, 紫：Garratt（1977）による経験式）

風速時に過剩な運動量を与えること，陸上地形の影響が 含まれないことが原因と考えられる．最大潮位偏差の推 算結果の差を平面的にみたところ，湾奥以外はそれほど 差がないが，湾奥においては非常に差が大きくなった。

\section{(4) 海面抵抗係数}

経験的台風モデルに対して $C_{D}$ の条件を変えて計算した 名古屋における結果を図-5に示す。青系の線は，海上 $10 \mathrm{~m}$ 風速 $U_{10}$ がある值以上のときに $C_{D}$ を一定とした場合 の結果である．波齢に依存するJanssenの海面抵抗係数と 本多・光易式の結果を比較すると, 最大潮位偏差はかな り異なり，Janssenの方が $1.45 \mathrm{~m}$ 大きく，かなりの過大評 価になった．観測值と比べて最もピーク值が近かったの は，本多・光易式で $U_{10} \geq 30 \mathrm{~m} / \mathrm{s}$ の $C_{D}$ を一定とした場合 であった。経験的台風モデルでも，バルクフラックスの パラメタリゼーションを適切に与えると，ある程度の精 度が確保できることがわかった。

\section{4. 台風特性が高潮予測に及ぼす不確実性}

\section{（1）台風経路}

図-6に，東に最大風速半径の $+18.5 \mathrm{~km}$ 平行移動し，回 転角度を変化させた場合の最大潮位偏差と経路の関係を 示す。東に $+18.5 \mathrm{~km}$ 移動し, 反時計回りに+20回転した 場合が，伊勢湾にとって最も危険な経路となり，最大高 潮偏差は $4.76 \mathrm{~m}$ となった。伊勢湾台風が元の経路を辿っ たときと比べると $1.34 \mathrm{~m}$ ，伊勢湾台風経路を単に+18.5 


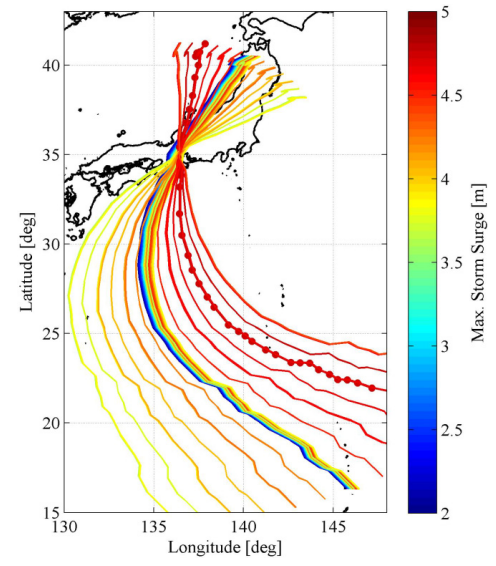

図-6 最大潮位偏差と台風経路の関係（色は名古屋港最大潮 位偏差, 丸付きの線：危険経路）

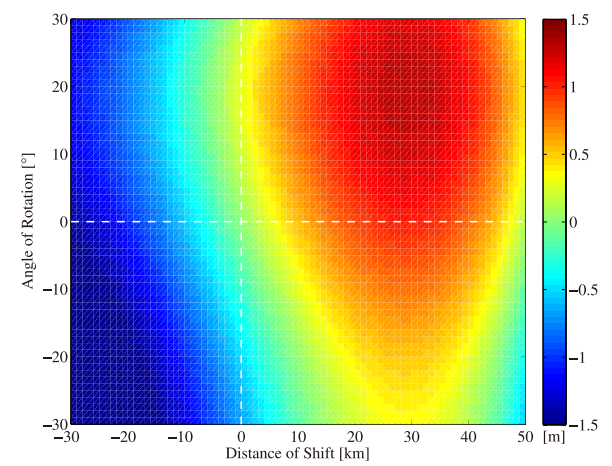

図-7 3 次多項式近似による平行移動距離・回転角度に伴う最 大潮位偏差の変化（横軸：平行移動距離（東を正）, 縦 軸：回転角度（反時計回りを正））

$\mathrm{km}$ 平行移動した場合よりも $0.40 \mathrm{~m}$ 増加した. 図示しない が，平行移動だけなら， $+25 \mathrm{~km}$ 移動した場合の方が，気 圧が $4 \mathrm{hPa}$ 低くなるために偏差が $0.8 \mathrm{~m}$ 大きくなるが，回 転を加味すると, $+18.5 \mathrm{~km}$ と $+20^{\circ}$ が最悪条件となった.

経験的台風モデルの台風経路を平行・回転移動したと きの最大潮位偏差の計算結果に 3 次多項式近似を適用し て図示したものが，図-7である，元の経路よりある程度 東に移動した方が，最大高潮偏差が極大值をとる。これ は，経路を東に平行移動した場合，伊勢湾上空の気圧が 低下し，風速も増加することによるものである。一方で, 回転角度が正方向（反時計回り）に大きくなれば，潮位 偏差のピーク值は大きくなる。これは吹きこみ角度の変 化による吹送距離の変化によるものである.

可能最大高潮を考える際, 経路を平行移動させるだけ でなく，経路を回転させて湾軸に対する進行方向を変え ることも，考慮すべき重要な要因であることがわかった．

\section{（2）台風移動速度}

図-8に名古屋港に打ける計算結果を示す。黒は移動速 度変化をさせない場合，つまり元の伊勢湾台風経路によ

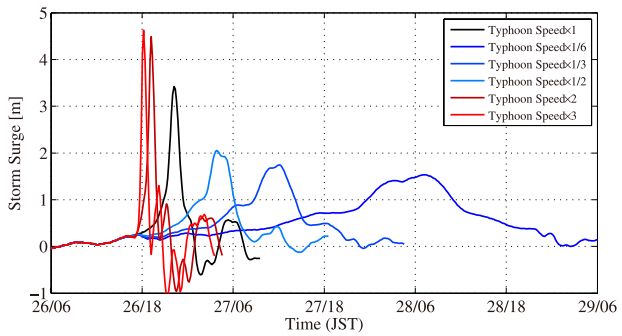

図-8 台風速度の違いによる名古屋における高潮偏差の時系 列比較（黒：移動速度変化なし, 青系：移動速度減少, 赤系：移動速度増加）

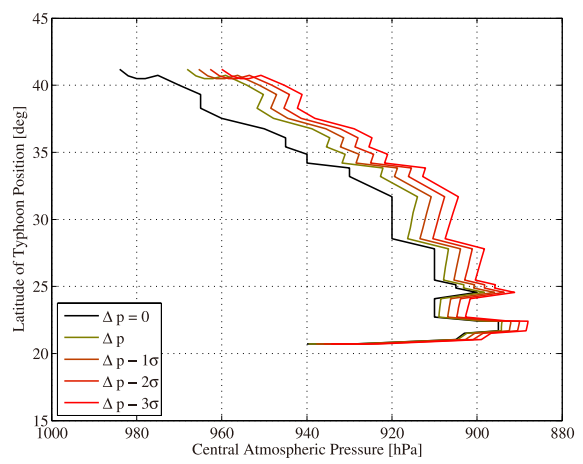

図-9 危険経路に将来変化傾向を与えたときの中心気圧（横 軸：中心気圧，縦軸：台風中心位置の緯度)

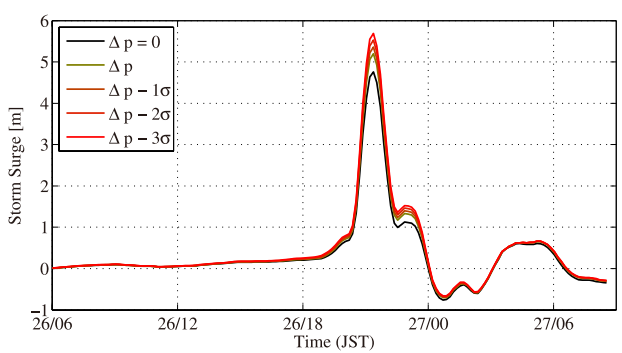

図-10 危険経路に想定した将来の中心気圧変化を与えた時の 名古屋における高潮偏差の時系列

る結果，青系の色は移動速度を減少させた場合，赤系の 色は移動速度を増加させた場合である．図より，移動速 度の増加に伴い，高潮偏差は増加することがわかる。そ れぞれ, $1.53 \mathrm{~m}, 1.74 \mathrm{~m}, 2.05 \mathrm{~m}, 4.49 \mathrm{~m}, 4.62 \mathrm{~m}$ であり, 移動速度を 3 倍に変化させた時の高潮偏差が最も大きか った，移動速度を減少させた時は，速度を変化させない 場合と比較すると高潮偏差は減少するが，高潮位の継続 時間は長くなるため, 満潮と重なる可能性が高くなる. 台風通過直後の潮位偏差の振動に着目すると, 理論通り 移動速度が大きくなるにつれて振動幅は大きくなり，移 動速度が小さくなるにつれて振動は小さくなる。

\section{（3）台風強度の将来変化}

最後に, 気候変動に伴う台風強度の変化を考慮した計 算を行った，台風強度の変化は中心気圧で表わせるもの 
表-1＼cjkstart計算モデルによる高潮偏差の変動量

\begin{tabular}{|c|c|c|c|c|}
\hline & 格子解像度 & ラディエーションストレス & 入力気象場 & 海面抵抗係数 \\
\hline 高潮変動量 & $\begin{array}{l}\text { 名古屋 : } 0.9 \mathrm{~m} \\
\text { それ外：0.3〜0.1 m }\end{array}$ & $\begin{array}{l}1.2 \sim 1.75 \mathrm{~m} \text { (伊勢湾奥) } \\
0.9 \sim 1.1 \mathrm{~m} \text { (三河㴒奥 })\end{array}$ & $\begin{array}{l}2.0 \mathrm{~m} \text { (経験的台風モデルー } \\
\text { 再解析值) }\end{array}$ & $1.45 \mathrm{~m}$ (Janssen一本多 . 光易) \\
\hline
\end{tabular}

表-2 台風特性による高潮偏差の変動量

\begin{tabular}{|c|c|c|c|c|}
\hline & 経路の東西位置 & 経路の方位 & 移動速度 & 気候変動による中心気圧 \\
\hline 高潮変動幅 & $-1.37 \sim 1.02 \mathrm{~m}(-30 \sim 50 \mathrm{~km})$ & $-0.67 \sim 0.40 \mathrm{~m} \quad\left(-30^{\circ} \sim+30^{\circ}\right)$ & $-1.89 \sim 1.20 \mathrm{~m} \quad(1 / 6 \sim 3$ 倍 $)$ & $0.43 \sim 0.93 \mathrm{~m} \quad($ mean, $+1 \sim 3 \sigma)$ \\
\hline 最大值 · 条件 & \multicolumn{2}{|c|}{$4.76 \mathrm{~m}$, 東方向へ $+18.5 \mathrm{~km} \&$ 反時計回りに+20 } & $4.62 \mathrm{~m}, 3$ 倍 & $5.69 \mathrm{~m},-\Delta p-3 \sigma[\mathrm{hPa}]$ \\
\hline
\end{tabular}

として, 中心気圧のみを変化（減少ならびに増加）させ た. 緯度依存する中心気圧の将来変化傾向 $\Delta p[\mathrm{hPa}$ を考 慮し, 将来気候下の極端な例を想定するために, 将来変 化傾向の標準偏差 $\sigma[\mathrm{hPa}]$ の変化も上乗せした.

図-9に危険経路の中心気圧に将来変化傾向を上乗せし た結果を，図-10に高潮計算結果を示す。かなり極端に $3 \sigma$ 変化させた場合, 中心気圧が約 $20 \mathrm{hPa}$ 低くなり, 強度 変化がない場合より, 高潮偏差は $4.76 \mathrm{~m}$ から $0.93 \mathrm{~m}$ 増加 し, $5.69 \mathrm{~m}$ となった. 予測変動幅は $0.43 \sim 0.93 \mathrm{~m}$ である.

\section{5. 結 論}

各検討要因に対して変動した高潮偏差を, 表-1および 2 にまとめて示す.

\section{（1）計算モデルが高潮予測に及ぼす不確実性}

格子解像度や計算格子, ラディエーションストレス, 入力気象場, 海面抵抗係数による高潮偏差に及ぼす不確 実性を評価したところ，海面抵抗係数と気象場が高潮偏 差に及ぼす影響が大きいことがわかった。

\section{（2）台風特性が高潮予測に及ぼす不確実性}

経験的台風モデルによって, 伊勢湾台風経路の平行・ 回転移動を施し, 高潮計算を行った結果, 一番大きい最 大高潮偏差を引き起こしたのは, 湾軸と平行に移動する 経路であり，最大で+1.34 mであった，移動速度は速く

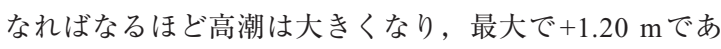
った。一方, 気候変動予測実験結果に基づいて, 台風中 心気圧の将来変化を強めに考慮した場合の最大值は $+0.93 \mathrm{~m}$ であった. 台風強度の変化による影響よりも, 台風経路のインパクトの方が大きいことがわかる.

以上のように，高潮偏差に及ぼす不確実性の要因とし て, インパクトの大きいものは, 入力気象場, 海面抵抗 係数, 台風経路, 速度であることがわかった. 今後, 高 潮に及ぼす気候変動の影響, 特に可能最大值を考える上 で, 台風強度の将来予測と共に, 個々の湾における台風 経路の不確実性の評価が重要であることを示した。

謝辞 : 本研究は, 文部科学省気候変動リスク情報創生プ ログラム, 科学研究費補助金の交付を受けて行った成果 であることを明記し，ここに謝意を表す。

\section{参 考 文 献}

柴木秀之・加藤史訓 · 山田浩次 (2001) : 密度成層とwave setup 考慮した土佐湾異常高潮の推算, 海岸工学論文集, 第 48 巻, pp.286-290.

藤井 健, 光田 寧 (1986) : 台風の確率モデルの作成とそれ による強風のシミュレイション. 京都大学防災研究所年 報, Vol. 29, No.B-1, pp.229-239.

別所康太郎・中澤哲夫ほか 10名（2010）：伊勢湾台風再現実験 プロジェクト（情報の広場）, 天気, Vol.57, No.4, pp.247-254.

本多忠夫・光易 恒（1980）：水面に及ぼす風の作用に関する 実験的研究, 第27回海岸工学講演会論文集, pp.90-93.

間瀬 肇・武藤遼太・森 信人・金洙列 · 安田誠宏 · 林 祐太 (2011) : 詳細気象予測值を用いた伊勢湾台風高潮の 再現実験, 土木学会論文集 B2 (海岸工学), Vol. 67, No. 2, pp.I_401-I_405.

村上智一・深尾宏矩・吉野 純ほか3名（2011）：温暖化によ る台風強大化に伴う東京湾での最大級高潮と波浪の時空 間分布, 土木学会論文集 B2 (海岸工学), Vol. 67, No. 2, pp.I_396-I_400.

安田誠宏・中條壮大 · 金 洙列 - 森 信人 · 間瀬 肇 - Kevin Horsburgh (2011)：気候変動予測実験出力を直接用いた高 潮リスクの評価, 土木学会論文集 B2 (海岸工学), Vol. 67, No. 2, pp.I_1171-I_1175.

吉野 純・ 小林孝輔 - 児島弘展 - 安田孝志 (2009) : 大気 ·海 洋力学的手法に基づく伊勢湾の可能最大高潮 - 波浪の評 価, 土木学会論文集 B2 (海岸工学), Vol. 65, No. 1, pp.396-400.

Garratt, JR.(1977): Review of drag coefficients over oceans and continents, Monthly Weather Review, Vol. 105, No. 7, pp.915929.

Kim, S. Y., Yasuda, T. and Mase, H.(2008): Numerical Analysis of Effects of Tidal Variations on Storm Surges and Waves, Applied Ocean Res., Vol. 30, pp.311-322, doi:10.1016/ j.apor.2009.02.003.

Kim, S. Y., Yasuda, T. and Mase, H.(2010): Wave set-up in the storm surge along open coasts during Typhoon Anita, Coastal Eng., Vol. 57, pp. 631-642, doi:10.1016/j.coastaleng.2010.02.004.

Kitoh A, Ose T, Kurihara K, Kusunoki S, Sugi M, KAKUSHIN Team-3 Modeling Group (2009): Projection of changes in future weather extremes using super-high-resolution global and regional atmospheric models in the KAKUSHIN Program, Hydrological Res. Letters, 3, pp.49-53. doi:10.3178/hrl.3.49.

Knutson T.R., McBride J.L., Chan J., Emanuel K., Holland G. et al. (2010): Tropical cyclones and climate change, Nature Geoscience, 3, pp.157-163, doi:10.1038/NGEO 779.

Mori, N., Yasuda, T., Mase, H., Tom, T.H., Oku, Y.(2010): Projection of Extreme Wave Climate Change under Global Warming, Hydrological Res. Letters, 4, pp.15-19, doi:10.3178/HRL. 4.15.

Mori, N. (2012): Projection of Future Tropical Cyclone Characteristics based on Statistical Model, In Cyclones Formation, Triggers and Control, Nova Science Publishers, Inc., 24p. 